This is the peer reviewed version of the following article: LANGLEY, C. R. (2017), Caring for Soldiers, Veterans and Families in Scotland, 1638-1651. History, 102: 5-23, which has been published in final form at

http://doi.org/10.1111/1468-229X.12327 . This article may be used for noncommercial purposes in accordance with Wiley Terms and Conditions for SelfArchiving. 
In July 1646, ministers gathered in Peebles, a small town just over twenty miles south of Edinburgh. After spending the previous two months investigating those who had supported the actions of James Graham, Marquis of Montrose and Charles I's lieutenant general in Scotland, this gathering ended on a different note. The Clerk recorded that 'the severall bretherene ar ordained...to exhibite the rolls of widowes and orphanes in ther severall congregationes the nixt day' so information could be sent to Edinburgh as soon as possible. ${ }^{1}$ Following its rush to prosecute royalist rebels, the Presbytery had turned its attention to rewarding those who had suffered for the cause of the National Covenant. The following week, all but four of the local parishes reported ten men who had died at the hands of royalist soldiers in the previous year: from casualties at local skirmishes to others who had died further afield in England and Ireland. More poignantly, the ministers listed twenty-seven individuals who were financially dependent on the soldiers: children, widows and, in two cases, their mothers. ${ }^{2}$ These individuals represent just a handful of those affected by the civil conflicts of the mid-seventeenth century with as many as 60,000 Scottish men killed and another 30,000 injured between 1638 and $1660 .^{3}$

The experience of soldiers who returned home and the sufferings of the families of those who did not has recently piqued scholarly interest. ${ }^{4}$ Historians assessing conflict in the seventeenth century have explored government-led initiatives to help, and in some cases compensate, soldiers or families affected by warfare. ${ }^{5}$ Much of this relief was organised centrally and then governed at the local level leaving significant room for regional variation in the quality and type of veteran care. In the same way as regular poor relief, aid for soldiers showed 'variety, agency and idiosyncrasy' in its local application. ${ }^{6}$

In many cases, historians have identified how petitioners developed a sense of 
entitlement from these forms of centralised welfare. Petitions from war widows frequently cited their husband's loyal service and how the system had failed to fully compensate them for their loss. ${ }^{7}$ Former royalist troops were not afraid to emphasise the loyal service that they had rendered for the King's cause in order to gain a favourable outcome. ${ }^{8}$ As an unintended consequence, systems designed to help those affected by warfare served to engage more people in political discussions. ${ }^{9}$

Historians assessing social care in Scotland assumed that similar forms of aid were not possible north of the Border. Rosalind Mitchison's work on social care concluded that mechanisms designed to alleviate poverty in Scotland were far less developed than those in England. Much of this rested on the assumption that the Scottish state did not have the ability to implement such policies because of 'a lack of practical experience in the actual running of the poor law'. ${ }^{10}$ In the absence of a centrally-directed movement, the work of Mitchison and others stressed the continuing prominence of 'permissive' approaches to welfare that promoted ad hoc collections and anonymous donations. By the early 1990s, the idea that local forms of charity operated in the absence of a state-led system was engrained into the historiography of Scottish welfare. ${ }^{11}$

More recently, however, studies of charity in Reformed territories across Europe contend that decentralised systems of relief may have been more effective than we once assumed. These studies have underlined how local charitable networks could provide adequate aid, despite not being state led or based on compulsory rates. Local authorities would target their, albeit meagre, resources in effective ways by often connecting charity to local disciplinary concerns. ${ }^{12}$ Following scholars who assess charity in other Reformed territories, those analysing relief structures in Scotland now appreciate how 'self help' proliferated and that those in need relied on 
local networks of kinship and reciprocity rather than the state. ${ }^{13}$ Moreover, ecclesiastical authorities did not aim to provide a comprehensive system of charity but, rather, one that complemented existing charitable structures. ${ }^{14}$ John McCallum went as far to suggest that official social care mechanisms were part of a wider 'ecology of relief' that encompassed both centralised and voluntary types of aid. ${ }^{15}$ The peculiar structure of the Kirk of Scotland established in the mid sixteenth century divided into a hierarchy of provincial synods, local presbyteries and parish-based consistories (kirk sessions) - provided an effective surrogate for a fully centralised system of relief.

How Scottish involvement in the wars of the seventeenth century affected poor relief remains unexplored. While we now know how the Civil Wars in Scotland created a politicised public discourse, there has been little attempt to explain how conflict affected Scotland's poor-relief arrangements. ${ }^{16}$ Parishes across Scotland certainly sought help from neighbouring settlements to repair damage caused by warfare, but scholars rarely explore the experience of the individuals involved. ${ }^{17}$ Detailed analysis of welfare systems designed to help those returning from conflict or their families - is lacking. Similarly, studies of the Cromwellian occupation from 1650 tend to concern themselves with how urban settlements tried to 'return to normality' rather than addressing how the new regime reintegrated former opponents or those otherwise affected by war. ${ }^{18}$ This omission is puzzling because the extant records of the Kirk of Scotland are remarkably complete, especially for Lowland areas, for the period between 1638 and 1660.

This article explores how Scottish welfare systems responded to the pressures of the Civil Wars. By assessing local ecclesiastical documents, one can see how casualties and their families were initially absorbed into existing structures - relying 
on local charity in much the same way as an ill or elderly parishioner. Central authorities acted to provide assistance as conflict spread in extent and ferocity. However, state intervention was not all encompassing and should not be read as an attempt to wrestle control of charitable structures from local authorities. Central aid was a temporary expedient to prevent the existing system from buckling under increased demand. The government still relied on local networks to organise its charitable campaigns, distribute relevant funds and continue helping those in need once official payments had stopped. Ad hoc payments and informal activities of parishioners persisted as the primary sources of help for those affected by conflict.

First Casualties: The Bishops' Wars

In February 1638, a group Scottish nobles and ministers gathered in the churchyard of Greyfriars, Edinburgh, to subscribe a document known as the National Covenant. The result of over a year of jockeying for position with the Crown, the Covenant required all subscribers to protect the peculiarities of the Scottish religious settlement. Both James VI/I and Charles I involved themselves in the details of Scottish Protestantism but over the course of the late 1630s a loose coalition emerged that opposed Royal policy. When Charles I convened a General Assembly - the highest ecclesiastical court in Scotland - to resolve the dispute at the end of 1638, radicals within the Covenanter group seized control, rejected the King's demands and proceeded to prosecute those who disagreed with them. ${ }^{19}$ In this revolutionary atmosphere, Covenanter leaders and the Crown prepared themselves for war but in the rush to mobilise troops, neither side developed a centralised method of post-bellum care. It 
fell to existing charitable structures to attend to the material needs of injured servicemen and the families they left behind.

Parish records recorded remarkably few soldiers affected by the First and Second Bishops' Wars in the Borders 1638 and 1640. Although the numbers of troops involved in these 'skirmishes' was considerable, the death toll was relatively low. ${ }^{20}$ In the aftermath of the conflict, individuals returned home and were supported by small, one-off, payments. In March 1640, the Synod of Lothian and Tweeddale ordered regional presbyteries to raise money for Robert MacMichael, who 'had his arme shot from him' while serving in a skirmish near the Border during the First Bishops' War. ${ }^{21}$ MacMichael personally petitioned for support. The numbers of supplicants from the Bishops' Wars remained relatively low and were supported by regular structures of poor relief. The session of Kelso, for example, recorded no charitable payments for soldiers during the Bishops' Wars, despite being the centre of military operations. $^{22}$ Instead, soldiers returning home received ad hoc support. The minister of Bolton, Haddington Presbytery, organised a voluntary contribution for soldiers who had returned to his parish in early $1641 .{ }^{23}$ Such references are incredibly rare, though, and one cannot discount the possibility that during this early part of the conflict parish clerks did not record casualties of the Bishops' Wars as soldiers but classified them as ordinary paupers. Despite such difficulties, it is clear that authorities absorbed these supplicants into existing poor relief structures.

Authorities treated the wives and families of men affected by war on a similar ad hoc basis to mitigate against the loss of male earning power. The parishes of Whitekirk and Tyninghame, Dunbar Presbytery, provided a payment of twenty-four shillings (the equivalent of over three weekly collections) to Agnes Ritchison and her sick children in December 1640 when her husband did not return from the army sent 
at the Border. ${ }^{24}$ Modern estimates suggest that a group of four children and two adults would have required between twenty-five to thirty shillings to purchase the minimum amount of food to sustain them per week. ${ }^{25}$ These payments were, therefore, deliberately limited in scope and sessions would only provide further help if conditions deteriorated. The following week, the session provided an additional, targeted, payment of twenty shillings to help purchase 'cures' for one of Ritchison's sick children. ${ }^{26}$ In January 1641, the session of Aberlady, Haddington Presbytery, ordered landowners who had sent men to fight with the Covenanter army to 'try [if] anie of ther wyves be in necessitie or want and to help thame'. This was another short-term measure and the session asked for a list of these individuals in case further charitable payments were needed. Two such women were supported with an extraordinary collection two months later when confirmation arrived that their husbands were 'deid at the campe'. ${ }^{27}$ While the size of payments received by these women varied, presumably based on the number of children each had, they only received one such payment. These payments did not represent pensions but, rather, short-term relief in extraordinary circumstances.

The soldiers and families affected by the two Bishops' Wars faced charitable competition from October 1641. The flight of Scottish expatriates from rebellion in northern parts of Ireland presented more targets for short-term charitable payments. These individuals were occasionally soldiers, but were more often the families of those who had suffered at the hands of rebels. ${ }^{28}$ The Synod of Lothian and Tweeddale was aware of the effect of the Rebellion on parochial poor funds, and advised that 'that which sould maintaine the poor of everie paroche is exceidinglie exhausted by...strangers who travell from place to place under pretence they were harried in Irland'. Local sessions and presbyteries, the Synod warned, should proceed with 
caution. ${ }^{29}$ Petitioners from Ireland continued to spread stories of massacre and atrocity across the Irish Sea and added a further burden on parish poor coffers across England, Scotland and Wales. ${ }^{30}$

One-off payments continued as a viable means of supporting the comparably low numbers of military casualties produced during the First and Second Bishops' Wars, as well as the first wave of supplicants fleeing from the Irish Rebellion. These supplicants rarely fit into the category of permanent pauper who received regular relief payments. Local authorities targeted Individual payments to stimulate recovery following an extraordinary event or misfortune.

\section{Centralised Aid}

The experience of crisis before 1642 was one of containment. Authorities continued to try to stimulate recovery with one-off payments if needed. However, the relatively low number of casualties from the two Bishops' Wars was not an accurate prediction of the scale of loss experienced in the following decade. The intensification of conflict after 1642 and aggressive plague outbreaks between 1644 and 1647 pushed regular structures of charity to a breaking point. ${ }^{31}$ Authorities required a more targeted approach to aid.

As demand for troops demands increased, authorities attempted to help those affected detrimentally by the conflict. Such help initially centred on legal waivers for the families of wealthy commanding officers. In June 1641 and again in January 1644, Parliament ordered the suspension of inheritance taxation when a soldier died 'in the defense and maintenance of the religion and of the laws and liberties of the kingdom during the present troubles'. ${ }^{32}$ Separate Parliamentart acts ordered other, 
one-off, payments for medical attention to prominent generals or the payment of a soldier's arrears in pay following a particularly damaging injury. ${ }^{33}$

Parliament turned its attention to less senior servicemen later in the year. In July 1644 Parliament ordered 'that all soldiers that have or shall willingly go out in the public service... and are or shall happen to be hurt and wounded in the defense of the public cause or in pursuing the enemies thereof that they are thereby disabled from their ordinary employments and working in their several callings and crafts and have no other means of maintenance for themselves, shall be maintained upon the public charges' in 'a competent way'. ${ }^{34}$ The act established a small committee in Edinburgh charged with assessing all 'losses, killed and lamed soldiers' and finding the financial resources to cover the expenses. An additional scheme extended this legislation to include the families of soldiers, too. These were not merely compensation claims: they were intended to prevent vulnerable individuals from falling into extreme poverty and having to rely on increasingly stretched parish coffers. $^{35}$

Under both schemes, Parliament made use of the well-established system of Church courts that spanned the breadth of the country. While the wives of higher ranking soldiers continued to petition Parliament directly, legislation recommended that ministers and sessions note details of the families of soldiers and their material circumstances. ${ }^{36}$ Presbyteries received these orders in the first part of 1646. In April, Jedburgh Presbytery instructed ministers to note 'lame soldiers hurt or mutilat in their warrs' in addition to the widows and orphans of those 'slaine be the enemie'. ${ }^{37}$ Once received by local presbyteries, individual sessions delegated the work among parish officers in order to verify the legitimacy of claims. The minister of Dunfermline ordered parish elders 'to give up thair rolls of the weidowes and orphanes in thair 
severall quarters of this paroche whose husbands was killed at the warrs conteining wher and when they died' ${ }^{38}$ In July of the same year, the session of Livingston received similar orders. ${ }^{39}$ In contrast to the English system of directing relief for injured soldiers from the local quarter session, in Scotland there was a clear connection between an apparently secular scheme and the comprehensive nexus of church courts in Scotland. Parliament used the highly developed nature of Church courts to gather information on the targets of charitable payments.

At the end of 1646, the system received a substantial financial boost that allowed an extension of the support programme. Under the terms of Scotland's agreement with the English Parliament to leave England, the Covenanting army received $£ 200,000$ Sterling in arrears. ${ }^{40}$ Authorities in Edinburgh earmarked five thousand pounds Sterling to soldiers who had served in England or wives and orphans of those who had died south of the Border. ${ }^{41}$ Local sessions and presbyteries were again deputed to define those who fell under the remit of the act.

The committee's charitable schemes were always temporary and were only renewed or extended following particularly troublesome passages of war. Moreover, whereas central funds paid for the first commission, renewed commissions relied on nationwide collections. Again, these were administered using the network of Church courts. Settlements in Argyll petitioned for charity following extensive rebel activity in December 1644 and January 1645 that saw the Marquis of Montrose and his accomplice, Alasdair MacColla, plunder Clan Campbell strongholds. Once authorities in Edinburgh were aware of the ferocity of the royalist assault, Parliament and the General Assembly ordered collections for prominent ministers displaced from Argyll in mid-1646 and collections for the laity in the region shortly afterward. ${ }^{42}$ Prominent 
widows from Argyll and Breadalbane petitioned Parliament at the end of 1646 for additional supply and had an act ratified on 1 January $1647 .^{43}$

If the Argyll campaign emphasised the heinous behaviour of royalist troops, details relating to individual soldiers and their families drew further attention to the Covenanted cause. The eleven women listed by Biggar Presbytery in April 1646 had lost husbands in five locations, ranging from Newark on Trent over two hundred and forty miles away to Kilsyth around forty miles distant, all sites of prominent Covenanter activity across England and Scotland. Later in May 1646, Ayr Presbytery noted how only those who had 'susteined [mortal] losses in the publict service against the rebells', and not the rebels themselves, were eligible for supply. ${ }^{44}$ Official proclamations made the comparison between righteous military activity and rebel action quite clear. In February 1647, when ordering the collection for Argyll, the session of Dunfermline made a point of stressing both 'the Lamentable condition of the distrest people in Argyll' and the 'bloodie rebells' who had caused the destruction. ${ }^{45}$ This deliberate policy of excluding those who had fought against the Covenant acted to promote the Kirk's cause amongst a war weary population. As a result, soldiers fighting against the Covenant were excluded. While Brechin Presbytery compiled a list of eligible widows and orphans in May 1646, it also ordered the creation of a document noting 'malignants with the qualities of thair malignancie'. ${ }^{46}$ Such charitable efforts were a crucial part of the Covenanted Kirk's scheme of persuasion and coercion: visibly removing those fighting against its interest from its charitable system.

In all of its efforts, the committee put pressure on local authorities to gather accurate information on those whop deserved charity. In 1647, members of Parliament conceded that, from their perspective, it was 'impossible to attain to a just 
and exact account of the names and number of the aforenamed soldiers and of their widows and others having interest in them ${ }^{47}$ The commissioners chose to estimate the level of human loss for each county and directed amounts of money basked upon the size of the local regiment. Rather confusingly, however, in the distribution of this aid, kirk sessions were expected to make 'ane extract roll of all common soldiers belonging to ther parishe of any regiments or companies spe[cifie]it in the act' ${ }^{48}$ Practical attempts to quantify how much aid an area required continued to rely on the knowledge of local officials.

The reliance on local structures could be problematic as other charitable business could overwhelm official demands to support soldiers. The particular focus on the sufferings of the population of Argyll, noted above, caused particular tension. St Andrews Presbytery protested to the Commission of the Kirk in early 1646 that the desired collection for the widows and orphans of Argyll would create 'a great outcrying...to have a collection in these bounds wher there are so many poore fathers and mothers...to whom help was promised by the Parliament, and are yet neglected'. ${ }^{49}$ The Presbytery feared that the Kirk leaders' emphasis on the sufferings of the people of Argyll diverted funds from local causes. Representatives returned from Edinburgh frustrated in March 1647 'that ther was no possible meanes of getting any course laid downe by the Parliament at this tyme for the help of oure poore widdowes, orphanes, old fathers and mothers who lived by there children... by the killing of these who belonged to them, in England and at home'. ${ }^{50}$ It was not until mid-1648 that parishes in the vicinity managed to gather their charitable contributions for Argyll. ${ }^{51}$ The Marquis of Argyll, whose lands Montrose had plundered, feared that parishes were making slow progress because of 'the apprehensions some had of the interverting of their charities', with the collection for Argyll representing an 
unwanted, distant, burden. ${ }^{52}$ Local necessities competed with the demands of central government. The minister of Dyce, Aberdeen Presbytery, failed to deliver the collection for Argyll, keeping it until it could be 'imployed on pious uses as occasion shall offer' in his parish. ${ }^{53}$ The session recorded that this money was still in its possession in July 1654 , perhaps indicating that they expected authorities to demand it at a later date ${ }^{54}$ Given that Parliament and the Commission of the Kirk attempted to provide strategic payments to local authorities to ease the burden of those affected by war, these examples underline an increased level of local expectation for central aid and the limitations of seventeenth-century central government to respond to these concerns.

Veterans and their families feared that other charitable business would push their own needs down the list of priorities. A petition presented to Parliament in January 1646 noted that whereas injured servicemen 'will plead for themselves, and the need the land has of their service will not permit [Parliament]...to forget them', 'the merit of the dead will have no memorial and the widows' and fatherless bill will be crushed in the crude throng of so many deserving petitioners'. ${ }^{55}$ Later in the same year, Samuel Rutherford asked parishes to pity the 'desolation, graves, multiplied widows and orphans' of the godly across England and Scotland. ${ }^{56}$ Tensions between local desires to ring fence aid and central desires to maintain the Covenanters' military force sat at the heart of such exchanges.

Occasionally, local documents hint at sinister motives behind these difficulties and friction between locally-elected officials and the intermediaries appointed by Parliament. In October 1648, Paisley Presbytery complained that a local patron, the Laird of Houston had 'thir long tyme deteined in his hands' the money gathered to help local widows and orphans. ${ }^{57}$ The ministers of the region, perhaps wisely, found 
no evidence that Houston was deliberately withholding the funds. The imputation of corruption was much clearer in a case in neighboring Lanark Presbytery. The Presbytery readied itself to distribute the money collected in mid-1648, only to find that the local landowner was not ready to release the funds. In December 1648, James Cunningham of Cobblehaugh responded that the delay was because officials in Edinburgh required a loan from him although he was quick to point out that 'he never received profite thereby'. ${ }^{58}$ The money was immediately transferred to the magistrates of Lanark to prevent further delay. The Council petitioned for further support two months later. ${ }^{59}$ Beyond strained relationships between local and central authorities, presbyteries struggled to obtain and then distribute these funds. Stranraer Presbytery complained in June 1649 that its share of the Parliamentary collection had never arrived, despite efforts to collect names and appoint commissioners for the distribution of the cash. Parliament ordered that local regiments of horse and foot should be quartered on those 'as shall be known to have in their hands the aforesaid sum... until payment be made' as punishment. ${ }^{60}$ These delays compounded problems of providing for individuals in need. The charitable landscape had changed by the time payments eventually arrived.

Local Church courts began to expect and actively solicit help from central authorities. Turriff Presbytery petitioned authorities in Edinburgh in April 1647 for a nationwide collection to help those injured or killed 'in difence of the cause of Christ' ${ }^{61}$ While unsuccessful, other petitions followed from elsewhere. In August 1649, presbyteries in Perthshire petitioned Parliament for the money promised to them in 1647 expressing their regret that some of the widows and orphans 'have lost greatly in waiting upon their part thereof, both their travel and expenses ${ }^{62}$ Local authorities demanded central intervention as delays in payment became increasingly 
unacceptable. Despite the central funds, parishes in Fife petitioned again in April 1650 'to find out a way how the woundit persones that are come fra the armie may be provydit for' ${ }^{63}$ Delays in delivery and the relatively small size of official donations did not alleviate concerns over the care of demobilised servicemen and their families.

This centrally-ordered system of relief was ambitious and illustrates a growing concern over the effects of conflict on day-to-day life and the danger of unbridled poverty. The system itself required a large degree of cooperation from local authorities and made particularly heavy use of the Church's network of presbyteries and kirk sessions. In most cases, the Kirk's instructions to collect and distribute financial support were highly effective and made a valuable impact on local circumstances. The government's payments were never intended as permanent aid and, as a result, demand always outstripped supply. Despite local requests for further charitable support from authorities in Edinburgh, central aid remained the exception rather than the rule.

\section{Continuing Local Support}

Beyond the commission's attempts to alleviate the effects of war, local aid continued to be the primary source of charity for veterans and their families. Local authorities continued to make ad hoc arrangements to provide care using existing funds and networks. As in England during the disruption of the 1650s, local authorities would regularly gather extraordinary collections for sick, injured or demobilised troops. ${ }^{64}$ While sessions expected social superiors to contribute generously to these collections, the organisation and distribution of funds was managed locally and without recourse to central authorities. ${ }^{65}$ In September 1646, the session of Gargunnock in Stirling 
Presbytery gave a small payment to Alexander Wood as he 'had one leg broke [and] immediately after the mending thereof...fell and broke the other leg... and because sundry times he had served in the paroch in exerciseing his calling and was but a poor man unable to help himself ${ }^{66}$ To the south west, the minister of Dumfries asked the town to support a badly injured soldier whose children had no means of income in $1650{ }^{67}$ These relief programmes targeted a small number of specific individuals. In September 1650, the ministers of Lanark Presbytery were ordered to gather an extraordinary collection to support the 'helping and cureing of the wounded men' returning from fighting the English invading force. The following month, the Presbytery responded that 'wounded men be maintained in theire severall paroches' but the record stops short of stating that such activity represented anything more than supplementary, occasional, payments. ${ }^{68}$ The use of extraordinary payments continued to occur as it had following the Bishops' Wars. The commissions' centralised payments had done little to change how charity operated at the local level.

Parliament officially sanctioned such local activity in 1649. Members ordered parishes to 'deal charitably' with the 'great number of indignent and distressed persons' across Scotland. ${ }^{69}$ The act stipulated that while those who could work were to find employment in newly established workhouses, those who could not were the subject of local, extraordinary, collections. Sessions across Scotland seized on two aspects of the act: firstly, that the collections continued to be discretionary and the responsibility of the local authority. Secondly, and most importantly, the act did not stipulate the creation of a system of permanent pensions. The act justifiably receives a great deal of attention in both contemporary accounts and subsequent assessments of the period but ultimately the status quo prevailed. ${ }^{70}$ 
The semblance of order suggested by the petitioning process and parliamentary sanctioned collections is misleading. In most cases, individual soldiers and their families continued to rely on local help. References to their names, occupations and physical condition litter kirk session records. In Chirnside Presbytery, the session of Hutton provided a one-off payment to Elizabeth Stewart in August 1654, as her husband was unable to provide for her financially as he had 'lost his leg' at the Battle of Worcester in $1651 .^{71}$ The parish of Whitekirk in Dunbar Presbytery provided a one-off payment to an unnamed soldier who the Clerk described as 'lame' after he had shown 's[i]x bloodie wounds' to the session. ${ }^{72}$ In Jedburgh Presbytery, the parish of Lilliesleaf continued to provide charitable contributions to individual soldiers throughout the late $1650 \mathrm{~s} .^{73}$ These actions of local government combined with the extraordinary payments of central authorities in Edinburgh to provide temporary relief for communities suffering from the long-term effects of conflict.

Parishes near to battlefield sites faced the prospect of supporting injured and displaced soldiers. The majority of such personnel were passing through en route to their home parish. Oliver Cromwell sent sixty wounded Scottish soldiers captured at a skirmish in Restalrig into Edinburgh in August 1650 and did the same with around five thousand wounded Scottish soldiers following the battle of Dunbar in September 1650 , a large number of whom died attempting to get home. ${ }^{74}$ The numbers of wandering soldiers finding their way home prevented the implementation of an orderly system of care. The session at Dunfermline could not record the names of all of the soldiers passing through their parish after the battle of Dunbar in September 1650 , noting that specific entries 'for the supply of woundit souldiers are missit in the minut booke'. ${ }^{75}$ In August 1651, the session of Dunfermline lamented the paucity of 
money available for poor relief and delayed its distribution of alms until the harvest labour market had removed those who were able to work from the parish. The session noted that only the physically disabled, including 'poore woundit sodgers', would receive assistance. ${ }^{76}$

This rather messy process could easily overwhelm parish authorities. Soldiers were worthy targets for limited amounts of parish charity but the high number of supplicants was problematic for parishes near prominent marching routes or major trade roads. In September 1651, the session of Dumfries appointed one of their local elders to 'anser the sojers (as they come to him) acceding to their seen necessities' ${ }^{77}$ Such requests became so pronounced in Whitekirk, Haddington Presbytery, that the session cancelled a meeting in November 1653 because 'they were troubled [by] souldiers and utter strangers who by their continual seeking of help defrauded the poor of the paroch of that [which] was collected to them' ${ }^{78}$ The committee's earlier intervention in providing centrally directed aid tried to reduce such problems was of little effect with such high demand. English troops occupying Aberdeen and Dalkeith made charitable contributions to the local authorities in order to appease both the soldiers and the needs of the local kirk session. ${ }^{79}$ Much to their chagrin, the sessions involved were in no position to turn down such assistance.

Limitations in the scope and nature of official charity meant that most of the care associated with soldiers actually occurred in parish households. Local kirk sessions contributed to, but did not dominate, these arrangements. In May 1646, the session of Ormiston, Dalkeith Presbytery, paid eight shillings to Archibald Napier for 'harbouring of ane distressed souldier and his wife', while the session of Ferry-Porton-Craig paid Isabel Key forty-eight shillings 'for keeping a soger that was sicke' in June. ${ }^{80}$ In November of the same year, the session of Dunfermline paid locals to 
provide for a winding sheet and a grave to be dug for 'ane callit Thomas Filpotts' a soldier who died when staying with unnamed parishioners in the north of the town. ${ }^{81}$ As far as we can tell from the records, carers were not obliged to provide such assistance but appear to have done so without the session's prior knowledge. These cases underline how the actual business of caring was largely organised and performed within the parish.

In addition to the costs associated with care, kirk sessions directed their limited resources towards supporting petitions for specialist medical procedures. Even in these cases, large-scale, regulated, payments were not the norm. These individuals had slowly made their way back to their homes in the north and received extraordinary payments for medical treatment. The record made no reference to paying for their subsequent care. In December 1646, the Dunfermline session paid a large sum to the local barber surgeon, Robert Shortus, 'for curing of some woundit souldiers who come fra Kilsyth', an amount swiftly forwarded to the surgeon 'in consideratioun of his [own] povertie and present necessity ${ }^{82}$ The session paid more barber surgeons in the aftermath of the battle of Dunbar in September 1650 'for peying the chirgians for curing' of 'woundit and hurt souldiers'. Similarly, the session of Lasswade, Dalkeith Presbytery, paid surgeons to operate on the 'deadlie wounded' James Ronald after the Battle of Dunbar. ${ }^{83}$ Further north, in October 1652, the Synod of Moray ordered 'thankfull acknowledgement' and a token payment to be made to William Yeoman, a surgeon who treated forty or fifty 'wounded souldiers who hade escaped with ther lives' from the Battle of Dunbar in 1650 and the Sack of Dundee in $1651{ }^{84}$ The lengthy journey home for such soldiers may have made their need for specialist medical attention more urgent. Across Scotland, kirk sessions contributed 
to the care of soldiers and their families, but their role was increasingly confined to providing one-off payments for specific needs.

The informality of this support extended to how local Kirk authorities stretched their own rules governing the movement of supplicants. It is quite clear that military supplicants travelled considerable distances to obtain charitable support despite prohibitions against individuals arriving at parishes without reliable letters of reference. ${ }^{85}$ In these cases, local sessions continued to use one-off payments to prevent wandering paupers remaining in the parish. Session clerks rarely referred to soldiers by name but, rather, used an adjective to describe their condition and the appellation 'soldier'. The Dundee Treasurers' book recorded a payment to an unnamed 'lein' soldier among supplicants for one-off charity in January $1650 .{ }^{86}$ Although their adherence to the Kirk's 'godly' cause was not always tested, the lack of real identification was unimportant if these figures promptly left the parish.

Soldiers and families exempted from official structures of charity received support by other means. Ecclesiastical authorities condemned any sort of compliance with Oliver Cromwell's army when it crossed the Tweed in July 1650 from sharing strategically important information, entering into sexual relations or providing food or drink. ${ }^{87}$ During the initial invasion skirmishes, ships ferried wounded English soldiers back to England to receive medical attention. ${ }^{88}$ A separate fund established by Parliamentary statute in September 1651 served to support those English soldiers and their families who had served for longer than a year. This act provided six months additional pay for either the injured soldier or the soldier's family until certification arrived relating to their injuries or service. ${ }^{89}$ Despite orders to the contrary, local kirk sessions showed favour to English soldiers when it was in their interests. In January 1652, the session of Ayr, Ayr Presbytery, criticised one parishioner for attacking 'hurt 
Englishmen...to the great prejudice of the toune'. ${ }^{90}$ The fear of English retribution, or fines for the upkeep of the injured soldier, forced the hand of communities. In November 1654, the council of Peebles also fined a local woman for assaulting a soldier in the English garrison. ${ }^{91}$ The local council in Leith went one step further and offered to build an alms house 'for maintenance of English souldiers maimed in the Scottish service and other English that may be reduced heir to great necessitie' in $1655 .^{92}$ Such efforts show how Scottish communities even developed informal carebased relationships for English troops.

\section{Conclusion}

The growing numbers of dead or injured servicemen in the Civil Wars forced subtle variations in the provision of welfare. Existing charitable structures absorbed the relatively small-scale losses suffered by Scottish communities during the Bishops' Wars: supported by extraordinary charitable collections and the myriad acts of private charity that went unreported by authorities. Refugees fleeing from Ireland in 1641 and 1642 added extra strain to this system but its operation continued. Heightened military activity, both within Scotland and beyond its borders from 1642, however, created unprecedented levels of demand. The actions of the committees for widows and fatherless children reflected an appreciation of the impact war was having on communities and the need to soften local losses by mobilising national resources. While the one-off payments distributed by the committee experienced delays and bottlenecks, Parliament only intended payments as a boost to regional coffers to temporarily alleviate local strain. 
It is perhaps unsurprising that historians have focused their attention on such centralised activity. When payments were forthcoming, governmental aid represented a large chunk of a parish's revenue. The ecclesiastical network of kirk sessions and presbyteries was an ideal device to gather the names of those most in need and then distribute financial aid. This process underlines the resilience of Church courts in Scotland even in the face of conflict. While we can observe failings in a handful of cases, perhaps implying some degree of corruption, these usually stemmed from the excessive involvement of a key individual rather than indicating some larger, systemic, failure. Indeed, it appears that the checks and balances developed in ecclesiastical administrative structures in the sixteenth and early seventeenth centuries were key to the success of the welfare system. Moreover, the deep links established between presbyteries and synods over the previous three-quarters of a century allowed genuine cooperation between centre and locality.

The government's actions did not remove the need for local aid systems. It was not the intention of central government to supplant local forms of aid with one, uniform, system governed from the capital. Official donations took the form of supplementary forms of relief and, arguably, aimed at maintaining civic stability at a time of intense internal pressure. Authorities renewed central provision only in exceptional circumstances and when central finances allowed. Local authorities continued to define disability, impoverishment and the deserving nature of a supplicant.

Official payments presaged one important development, though. While central government did not intend to take over charitable business, local authorities became increasingly eager for central help. In this way, burgh magistrates were ready to accept increasingly rigourous demands from senior authorities in exchange for the 
help they could provide (especially when faced with unprecedented levels of demand). One observes tension between these two forces in two sets of circumstances. First, Covenanter leaders expected parishes to support causes far removed from their locality in exchange for central help. Collections for the distressed inhabitants of Argyll were the cost parishes on the East Coast had to pay for increasing support from the centre. Secondly, parishes became increasingly disappointed when central authorities did not have the ability to support them.

The significant overlap between the informal and the institutional presents a much more complex picture of how communities in Scotland, and early-modern Europe in general, operated. ${ }^{93}$ Those affected by war continued to rely on a combination of financial support (family, neighbours and authorities) and received care in a variety of contexts (specialist physicians, burgh hospitals, homes of family members or strangers). Such systems formed part of a larger structure of relief that continued to operate throughout the Civil Wars. 


\section{Notes}

1. National Records of Scotland [hereafter NRS], CH2/295/3, Peebles Presbytery minutes (1644-9), f. 43.

2. Ibid., ff. 44-6.

3. C. Carlton, Going to the Wars: The Experience of the British Civil Wars, 1638-1651 (new edn., London, 1994), pp. 213-215; I. Gentles, The English Revolution and the Wars in the Three Kingdoms, 1638-1652 (Harlow, 2007), ch. 15.

4. D. J. Appleby, 'Unnecessary persons?: Maimed soldiers and war widows in Essex 1642-1662', Essex Archaeology and History, 32 (2001), p. 209.

5. Carlton, Going to the Wars, pp. 346-8; G. L. Hudson, 'The relief of English disabled ex-sailors, c. 1590-1680', in C. A. Fury (ed.), The Social History of English Seamen, 1485-1649 (Woodbridge, 2012), pp. 233-8; E. Petersson, 'Wounded veterans and the state: The precursor of the Veterans' Home in Sweden (1560-1660)', Scandinavian Journal of History, 39/2 (2014), pp. 186-91.

6. D. J. Appleby, 'Veteran politics in Restoration England, 1660-1670', The Seventeenth Century, 28/3 (2013), pp. 324-8; P. Withington, 'Citizens, soldiers and urban culture in Restoration England', English Historical Review, 123 (2008), pp. 599-609; B. Capp, England's Culture Wars: Puritan Reformation and its Enemies in the Interregnum, 1649-1660 (Oxford, 2012), pp. 117-18; K. Wrightson, 'The politics of the parish in early modern England', in P. Griffiths, A. Fox and S. Hindle (eds), The Experience of Authority in Early Modern England (Basingstoke, 1996), pp. 21-6.

7. G. L. Hudson, Negotiating for blood money: War widows and the courts in seventeenth-century England', in J. Kermode and G. Walker (eds), Women, Crime and the Courts in Early Modern England (London, 1994), pp. 148-50.

8. M. Stoyle, '"Memories of the maimed": The testimony of Charles I's former soldiers, 1660-1730', History, 88/29 (2003), pp. 211-12.

9. M. Neufeld, 'The framework of casualty care during the Anglo-Dutch Wars', War in History, 19 (2012), pp. 434-7.

10. R. Mitchison, 'The making of the old Scottish poor law', Past and Present, 63 (1974), p. 61; Idem, The Old Poor Law in Scotland: The Experience of Poverty, 1574-1845 (Edinburgh, 2000), pp. 12-17, 25. 
11. R. A. Houston, The Population History of Britain and Ireland 1500-1750 (Basingstoke, 1992), pp. $69-70$.

12. H. Dingwall, Late Seventeenth-Century Edinburgh (Aldershot, 1994), pp. 248-9; M. Dinges,

'Huguenot poor relief and health care in the sixteenth and seventeenth centuries', in R. A. Mentzer and A. Spicer (eds), Society and Culture in the Huguenot World 1559-1685 (Cambridge, 2002), pp. 157-

74; T. Fehler, 'The burden of benevolence: Poor relief and parish finance in early modern Emden', in B. A. Kümin (ed.), Reformations Old and New: Essays on the Socio-Economic Impact of Religious Change (Aldershot, 1996), pp. 232-3; M. Olson, Calvin and Social Welfare: Deacons and the Bourse Française (London, 1989), 134-45.

13. S. Hindle, On the Parish? The Micro-Politics of Poor Relief in Rural England, c.1550-1750 (Oxford: Oxford University Press, 2004), 96-117; I. Krausman Ben-Amos, The Culture of Giving: Informal Support and Gift Exchange in Early Modern England (Cambridge, 2008), pp. 83-4; E. Van Nederveen Meerkerk and D. Teeuwen, 'The stability of voluntarism: Financing social care in early modern Dutch towns compared with the English poor law, c. 1600-1800', European Review of Economic History, 18/1 (February, 2014); R. A. Houston, Bride Ales and Penny Weddings: Recreations, Reciprocity and Regions in Britain from the Sixteenth to the Nineteenth Century (Oxford, 2014), pp. 177-80; E. P. Dennison, G. DeBrisay and H. L. Diack, 'Health in the two towns', in E. P. Dennison, D. Ditchburn and M. Lynch (eds), Aberdeen before 1800: A New History (East Linton: Tuckwell Press, 2002), p. 78; J. McCallum, Poor Relief and the Church in Early Modern Scotland (Edinburgh, forthcoming), ch. 8.

14. K. J. Cullen, Famine in Scotland: The 'Ill Years' of the 1690s (Edinburgh, 2010), pp. 95-7; R. E. Tyson, 'Poverty and poor relief in Aberdeen, 1680-1705', Scottish Archives, 8 (2002), p. 41.

15. J. McCallum, '"Nurseries of the poore": Hospitals and almshouses in early modern Scotland', Journal of Social History, 48/2 (2014), pp. 428, 431; Idem, 'Charity doesn't begin at home: Ecclesiastical poor relief beyond the parish, 1560-1650', Journal of Scottish Historical Studies, 32/2 (2012), p. 109.

16. L. A. M. Stewart, Rethinking the Scottish Revolution: Covenanted Scotland, 1637-51 (Oxford, 2016); C. R. Langley, Worship, Civil War and Community, 1638-1660 (London, 2016).

17. J. Barrett and A. Mitchell, Elgin's Love Gift: Civil War in Scotland and the Depositions of 1646 (Chichester, 2007), pp. 47-51; G. DesBrisay, “"The civill warrs did overrun all”: Aberdeen, 1630- 
1690', in E. P. Dennison, D. Ditchburn and M. Lynch (eds), Aberdeen before 1800: A New History (East Linton: Tuckwell Press, 2002), pp. 261-4.

18. T. M. Devine, 'The Cromwellian union and the Scottish burghs: The case of Aberdeen and Glasgow, 1652-60', in J. Butt and J. T. Ward (eds), Scottish Themes: Essays in Honour of Professor S. G. E. Lythe (Edinburgh, 1976), pp. 12-15; S. Gillanders, 'The Scottish burghs during the Cromwellian occupation, 1651-1660', unpublished PhD thesis (University of Edinburgh, 1999), pp. 149-72.

19. Langley, Worship, Civil War and Community, ch. 1; Stewart, Rethinknig the Scottish Revolution, ch. 2 .

20. D. Stevenson, The Scottish Revolution 1637-44 (reprint, Edinburgh, 2003), pp. 141-50.

21. NRS, CH2/424/3, Dalkeith Presbytery minutes (1639-52), f. 35; NRS, CH2/242/3, Linlithgow Presbytery (1639-53), f. 27.

22. NRS, CH2/1173/1, Kelso kirk session minutes (1622-47), ff. 113-60.

23. NRS, CH2/185/5, Haddington Presbytery minutes (1639-48), f. 81.

24. NRS, CH2/359/1, Whitekirk and Tyninghame kirk session minutes (1615-50), f. 116.

25. A. J .S. Gibson \& T. C. Smout, Prices, Food and Wages in Scotland 1550-1780 (Cambridge, 1995), p. 364; C. R. Langley, 'Lying sick to die: Dying, informal care and authority in Scotland, c.1600-1660', Sixteenth Century Journal (forthcoming).

26. NRS, CH2/359/1, Whitekirk and Tyninghame kirk session minutes (1615-50), f. 116v.

27. NRS, CH2/4/1, Aberlady kirk session minutes (1632-45), f. 60-1.

28. J. R. Young, "“Escaping massacre": Refugees in Scotland in the aftermath of the 1641 Ulster Rebellion', in D. Edwards, P. Lenihan and C. Tait (eds), Violence and Political Conflict in Early Modern Ireland (Dublin, 2007), pp. 228-9.

29. NRS, CH2/424/3, Dalkeith Presbytery minutes (1639-52), f. 358.

30. K. J. Lindley, 'The impact of the 1641 Rebellion upon England and Wales, 1641-5', Irish Historical Studies, 18 (1972), pp. 147-9; C. R. Langley, 'Sheltering under the Covenant: The National Covenant, Orthodoxy and the Irish Rebellion, 1638-1644', Scottish Historical Review (forthcoming, 2016).

31. M. Flinn et al, Scottish Population History: From the 17th Century to the 1930s (Cambridge, 1977), pp. 136-47. 
32. K. M. Brown et al (eds), Records of the Parliaments of Scotland to 1707 [hereafter RPS] (St Andrews, 2007-16), 1641/7/33; 1644/1/19. Date accessed: January 2015.

33. RPS, 1644/6/91; RPS, 1645/1/2.

34. $R P S, 1644 / 6 / 290$.

35. Barrett and Mitchell, Elgin's Love-Gift, p. 44.

36. $R P S, 1645 / 1 / 42$.

37. NRS, CH2/198/3, Jedburgh Presbytery minutes (1644-58), f. 72.

38. NRS, CH2/592/1/1, Dunfermline kirk session minutes (1640-98), f. 41v.

39. NRS, CH2/467/1, Livingston kirk session minutes (1641-7), f. 50.

40. D. Stevenson, 'The financing of the cause of the Covenants, 1638-51', Scottish Historical Review, 51 (1972), pp. 109-10; Idem, Revolution and Counter Revolution 1644-51 (reprint, Edinburgh, 2003),

pp. 63-7; L. A. M. Stewart, 'English funding of the Scottish armies in England and Ireland, 1640-1648', Historical Journal, 52/3 (2009), p. 583.

41. RPS, $1646 / 11 / 45$. This amounts to around sixty-thousand Pounds Scots. See Gibson \& Smout, Prices, Food and Wages, p. xv.

42. J. Spalding, The History of the Troubles and Memorable Transactions in Scotland, from 1624-1645 (Aberdeen, 1830), p. 470; A. Peterkin (ed.), Records of the Kirk of Scotland. Containing the Acts and Proceedings of the General Assemblies, from the Year 1638 Downwards (Edinburgh, 1838), p. 452. 43. A. F. Mitchell and J. Christie (eds), Records of the Commissions of the General Assemblies of the Church of Scotland, I (Edinburgh, 1892), pp. 147, 190.

44. NRS, CH2/532/1, Ayr Presbytery minutes (1642-51), f. 256.

45. NRS, CH2/592/1/1, Dunfermline kirk session minutes (1640-89), f. 52.

46. NRS, CH2/40/1, Brechin Presbytery minutes (1639-61), f. 72.

47. $R P S, 1646 / 11 / 26$.

48. NRS, CH2/295/3, Peebles Presbytery minutes (1644-9), f. 60.

49. G. Kinloch (ed.), Selections from the Minutes of the Presbyteries of St Andrews and Cupar MDCXLI-MDCXCVIII (Edinburgh, 1837), p. 36.

50. Ibid., p. 36 .

51. NRS, CH2/1543/1, Crail kirk session minutes (1648-84), f. 10; NRS, CH2/723/2, Dunblane Presbytery minutes (1648-52), ff. 1-2. 
52. Commissions, I, p. 219.

53. NRS, CH2/117/1, Dyce kirk session minutes (1643-76), ff. 27, 33, 86.

54. Ibid., f. 30.

55. RPS, 1645/11/157.

56. S. Rutherford, The Divine Right of Church-Government and Excommunication (London, 1646), introduction.

57. NRS, CH2/294/3, Paisley Presbytery minutes (1647-60), f. 24.

58. NRS, CH2/234/1, Lanark Presbytery minutes (1623-57), f. 179; RPS, 1648/3/79.

59. R. Renwick (ed.), Extracts from the Records of the Royal Burgh of Lanark (Glasgow, 1893), pp.

137-8. Collections for refugees from the Irish Rebellion experienced similar problems. See Young,

“"Escaping massacre”, p. 222.

60. $R P S, 1649 / 5 / 179$.

61. NRS, CH2/1120/1, Turriff Presbytery minutes (1642-88), f. 86.

62. $R P S, 1649 / 5 / 341$.

63. NRS, CH2/154/2/1, Synod of Fife minutes (1639-57), f. 219.

64. R. W. Herlan, 'Poor relief in London during the English Revolution', Journal of British Studies, 18 (1979), pp. 46-7.

65. L. A. M. Stewart, 'Poor relief in Edinburgh and the famine of 1621-24', International Review of Scottish Studies, 30 (2005), pp. 11-13.

pp. 8-9.

66. NRS, CH2/1121/1, Gargunnock kirk session minutes (1625-58), f. 71.

67. NRS, CH2/537/13, Dumfries kirk session minutes (1648-61), f. 19.

68. NRS, CH2/234/1, Lanark Presbytery minutes (1623-57), ff. 457-8.

69. $R P S, 1649 / 1 / 192$.

70. R. Mitchison, 'Permissive poor laws: The Irish and Scottish systems considered together', in S. J.

Connolly, R. A. Houston and R. J. Morris (eds), Identity and Economic Development: Ireland and Scotland, 1600-1939 (Preston, 1995), p. 162; Idem, The Old Poor Law in Scotland, pp. 22-3; T.

Ferguson, The Dawn of Scottish Social Welfare: A Survey from Medieval Times to 1863 (Edinburgh, 1948), p. 5; A. A. Cormack, Poor Relief in Scotland: An Outline of the Growth and Administration of the Poor Laws in Scotland (Aberdeen, 1923), pp. 53-5. 
71. NRS, CH2/466/1, Hutton kirk session minutes (1649-77), f. 50.

72. NRS, CH2/359/1, Whitekirk and Tyninghame kirk session minutes (1615-1650), f. 30.

73. NRS, CH2/241/5, Lilliesleaf kirk session minutes (1649-1676), ff. 13-15.

74. J. Nicoll, A Diary of Public Transactions (Edinburgh, 1836), p. 22; B. Whitlocke, Memorials of the English Affairs from the Beginning of the Reign of Charles the First to the Happy Restoration of King Charles the Second, III (Oxford, 1853), p. 238.

75. NRS, CH2/592/1/1, Dunfermline kirk session minutes (1640-89), f. 115v.

76. Ibid., f. 121.

77. NRS, CH2/537/13, Dumfries kirk session minutes (1648-61), f. 25. My emphasis.

78. NRS, CH2/359/1, Whitekirk and Tyninghame kirk session minutes (1615-50), f. 18.

79. Langley, Worship, Civil War and Community, ch. 2.

80. NRS, CH2/150/1, Ferry-Port-on-Craig kirk session minutes (1640-74), f. 17.

81. NRS, CH2/592/1/1, Dunfermline kirk session minutes (1640-89), f. 50.

82. Ibid., f. 50v.

83. NRS, CH2/471/2, Lasswade kirk session minutes (1637-55), f. 155.

84. NRS, CH2/271/2, Synod of Moray minutes (1646-68), f. 237; NRS, CH2/839/2, Speymouth kirk session minutes (1651-8), f. 7v.

85. Peterkin, Records, p.333; NRS, CH2/1120/1, Turriff Presbytery minutes (1642-88), f. 200; NRS, CH2/154/2/1, Synod of Fife (1639-57), f. 278.

86. NRS, CH2/1218/16, Dundee kirk session Treasurers' accounts (1640-1705), f. 320.

87. F. Dow, Cromwellian Scotland 1651-1660 (Edinburgh, 1979), ch. 1; R. S. Spurlock, Cromwell and Scotland: Conquest and Religion 1650-1660 (Edinburgh, 2007), pp. 18-31.

88. Whitelocke, Memorials of the English Affairs, III, p. 227.

89. C. H. Firth and R. S. Rait (eds), Acts and Ordinances of the Interregnum, 1642-1660 (London, 1911), pp. 556-9.

90. NRS, CH2/751/3/1, Ayr kirk session minutes (1646-53), ff. 205-6.

91. R. Renwick (ed.), Extracts from the Records of the Burgh of Peebles, 1652-1714 (Glasgow, 1910), p. 25 .

92. Wood (ed.), Extracts, pp. 410-12.

93. J. Goodare, State and Society in Early Modern Scotland (Oxford, 1999), pp. 172-3. 